\title{
Not Known if RET Rearrangement Analysis Was Performed
}

National Cancer Institute

\section{Source}

National Cancer Institute. Not Known if RET Rearrangement Analysis Was Performed. NCI Thesaurus. Code C160466.

An indication that it is not known whether RET rearrangement analysis was performed during the study. 